\title{
Comparative Evaluation of Bond Strength of Self- Etching and Total Etch Dental Adhesive Systems to Dentin of Deciduous and Permanent Teeth
}

\author{
Evaluación Comparativa de la Fuerza de Unión de los Sistemas de Adhesivo Dental \\ Autograbado y Grabado Total para la Dentina de Dientes Deciduos y Permanentes
}

\author{
C. A. Martínez-Carrascoํ'; A. Nevárez-Rascón ${ }^{2} \&$ U. Soto-Barreras ${ }^{2}$
}

MARTíNEZ-CARRASCO, C. A.; NEVÁREZ-RASCÓN, A. \& SOTO-BARRERAS, U. Comparative evaluation of bond strength of self-etching and total etch dental adhesive systems to dentin of deciduous and permanent teeth. Int. J. Odontostomat., 14(1):55-59, 2020.

ABSTRACT: The aim of this study was to analyze the bond strength of total-etch and self-etch adhesive systems to dentin of primary and permanent teeth. Methods: Thirty sound naturally exfoliated primary molars deciduous teeth (DT) and thirty sound permanent bicuspids permanent teeth (PT) were randomly divided into six groups ( $n=10$ per group) according to two commercial adhesive systems: Adper Single Bond 2; 3M ESPE (Total-etch) and Adper Easy Bond; 3M ESPE (selfetch and total-etch). Specimens submitted to cyclic loading in a universal Instron testing machine. Bond strength values $(\mathrm{MPa})$ were analyzed by ANOVA test and Duncan post hoc test $(\mathrm{a}=0.05)$. Results: Mean values were higher in PT compared to DT. In deciduous teeth, no significantly differences observed. Total etch AdperTM Single Bond 2 showed significantly higher bond strength than self-etch AdperTM with additional acid etching in PT $(p=0.031)$. Conclusion: Our findings suggest that the highest bond strength was found in dentin tissue of PT with total etch AdperTM employing the adhesive the Single Bond 2 of one step self-etch.

KEY WORDS: adhesive systems, bond strength, permanent and deciduous teeth.

\section{INTRODUCTION}

The dentin tissue is a heterogeneous structure consisting of dentinal tubule surrounded by a highly mineralized tubular wall called peritubular dentin, which in turn imbedded within a partially mineralized collagen matrix called intertubular dentin (Mai et al., 2010).

Number and diameter of dentinal tubules increases as they approach to dental pulp, but some characteristics like structural heterogeneity, presence of dentinal fluid (relative humidity) and low surface energy, make of this tissue, a unique adhesive substrate for different adhesive systems (Chowdahary \& Subba Reddy, 2010). Successful adhesion to dentine is accomplish with an appropriate surface treatment (Mazzeo et al., 1995). Current adhesive systems employ two different ways to achieve the micromechanical properties of the dentin/adhesive in- terface. The first mechanism consists in the complete removal of the smear layer and the demineralization of the undamaged surface of the dentin by etching the dental substrate with phosphoric acid followed by the application of a primer and a bond resin (Mortazavi et al., 2004). The second method simplifies steps through the application of a self-etching system, which leaves the smear layer of the dentin as a bonding substrate. Nevertheless, chemical, physiological and micromorphological differences among permanent teeth (PT) and deciduous teeth (DT) are not fully understood (Schmitt \& Lee, 2002).

Previous studies have shown lower bonding strength in DT compared to PT (Agostini et al., 2001). In addition, DT present a minor concentration and diameter of dentinal tubules (Hegde \& Bhandary, 2008).

\footnotetext{
${ }^{1}$ MSD. Práctica privada, Cd Juárez, México.

${ }^{2}$ Departmento de investigación. Facultad de Odontología de la Universidad Autónoma de Chihuahua, México.
} 
Furthermore, peritubular dentin has been reported up to five times thinner in DT which leads to lower moisture (Mazzeo et al.; Prabhakar et al., 2003; Stanlin et al., 2005; Cavalcanti et al., 2008; Chowdahary \& Subba Reddy), as well as greater reactivity to acid conditioning (Nör et al., 1996). The stable adhesion between resin and dentin represents a fundamental requirement for clinical success and it depends on the proper interaction between the dental substrate, the adhesive system and the restoration (Castro et al., 2007). In agreement with García-Godoy \& Donly (2002), a minimum bonding force of 17-20 $\mathrm{MPa}$ is necessary to withstand the contraction force of the composite resin in the enamel and dentin Therefore, the purpose of this research was to compare the bonding strength of total etch and self-etch adhesive systems on primary deciduous teeth as well as on permanent teeth.

\section{MATERIAL AND METHOD}

In the present in vitro study, 30 sound primary molars next to exfoliate and 30 sound permanent bicuspids with complete rizogenesis and removed for orthodontic reasons, were distributed in six groups of 10 specimens each (Table I). All specimens with solid physiological faces and without any associated pathologies, were autoclaved for 20 minutes at a $120^{\circ} \mathrm{C}$ temperature employing a M7 Speed Clave Sterilizer (Midmark Corporation, OH. U.S.A), according to the methodology employed by Jaques \& Hebling (2006), and randomly distributed through Research

Table I. Group's distribution.

\begin{tabular}{cclc}
\hline Group & $\mathrm{n}$ & Mean-SD(MPa) & Duncan $^{*}$ \\
\hline A & 10 & $16.87 \pm 9.5$ & 1,2 \\
B & 10 & $12.97 \pm 8.0$ & 1 \\
C & 10 & $17.43 \pm 9.9$ & 1,2 \\
D & 10 & $38.86 \pm 20.4$ & 3 \\
E & 10 & $28.67 \pm 13.2$ & 2,3 \\
F & 10 & $26.54 \pm 9.2$ & 2 \\
\hline
\end{tabular}

Randomizer V 3.0 into six groups.

Sample preparation. The specimens were mounted in a PVC loop at $90^{\circ}$, in accordance to ISO/TS 11405 , 5.2.2.5. Afterwards, the composite resin Filtek Z350 XT (3M ESPE, St. Paul, MN, USA) was prepared, through the ISO 4049:2000, 7.10.1.1. All composites were calibrated through a micrometer with the following dimensions: $4 \mathrm{~mm}$ in diameter and $6 \mathrm{~mm}$ height. According to ISO/TS 1205, 2003, 5.2.4.4 Standard, the enamel of vestibular surface was removed with a conical shape burr (ISO 173/018 burr). The dentin tissue exposed by using a Diamond Wheel (ISO 068/041 burr) placed on a hand-piece Midwest Tradition PB Non-fiber-Optic High-Speed (Densply, IL, USA). Wearing procedures considered $1.5 \mathrm{~mm}$ in depth and $3 \mathrm{~mm}$ in diameter. Specimen's exposed surfaces were previously embedded with $37 \%$ orthophosphoric acid by 20 seconds (Ormco, Orange, CA, USA) and polished with pumice stone before the adhesion procedure. Furthermore, in groups of total etch; a $32 \%$ etching gel (Scotch bond Universal etchant 3M ESPE, St. Paul, MN, USA) applied for 20 seconds, after that a $2 \%$ Chlorhexidine (Concepsis Ultradent, South Jordan, UT USA) applied on dentin exposed for 10 seconds also irrigated with distilled water for 10 seconds and dried with compressed air for 5 seconds. On self-etching groups, only the chlorhexidine procedure was applied. Finally, the adhesion procedure was carried out in accordance with the manufacturer's instructions, employing a light curing lamp of $1200 \mathrm{~mW} / \mathrm{cm}$ Elipar LED (3M ESPE, St. Paul, MN, USA) to all the composites.

Specimen's storages. All specimen's was maintained in an aseptic glass with distilled water at room temperature once they were recollected and after the composites adaptations procedures, in order to avoid dehydration and alteration of collagen structure.

Bonding and failure analysis. Specimens were placed in a loading loop in a universal testing machine (Instron 4469 machine) and programmed to a compression charge of $0.5 \mathrm{~mm} / \mathrm{min}$. Bond strength values were recorded in Mega Pascal's (MPa). Finally, the amount of adhesive left on the tooth after the test evaluation under stereomicroscope (Leica EZ4HD) at 35 fold magnifications. The Adhesive Remnant Index (ARI) system was used to explore the microscopic debonding mechanism of the dentin/ hybrid layer/resin adhesive interface. All the results expressed as the mean and \pm standard deviation. $Q$ test at $95 \%$ reliability carried out for identification and rejection of outliers. Shapiro-Wilk and Brown Forsythe tests employed to assess the normality of the data distribution). One-way ANOVA test and Duncan post hoc procedures used to compare differences between groups. Data were analyzed using the IBM SPSS statistics 23 program (IBM, SPSS Statistics 23 Chicago. USA). Statistical significance was set at $a=0.05$. 


\section{RESULTS}

On Table II, distributions of shear bond strengths values in the various adhesives systems described by groups were A, B, C correspond deciduous teeth (DT) strengths values and D.E, $F$ corresponded permanent teeth (PT) strengths values. Respect to the comparison of bonding strength values between PT and DT, specimens of PT showed the greater bonding strength values $(p<0.05)$,

*Duncan post hoc: Groups with the same numbers denote that there was no statistical difference.

Comparing the bond strengths values on PT and DT by groups and according to the adhesive system, it was found a significant higher values $(p<0.05)$ in PT when a total etch Adper Single Bond 2 and self-etch were used in group $D$.

Table II. Shear bond strength tests results of six groups.

\begin{tabular}{cll}
\hline Group & \multicolumn{1}{c}{ Adhesive System } & \multicolumn{1}{c}{ Technique } \\
\hline A & Adper Single Bond 2 (3M & Total-etch Deciduous Teeth \\
B & Adper Easy Bond (3M ESPE) & Self-etch Deciduous Teeth \\
C & Adper Easy Bond (3M ESPE) & Total-etch Deciduous Teeth \\
D & Adper Single Bond 2 (3M & Total-etch Permanent Teeth \\
E & Adper Easy Bond (3M ESPE) & Self-etch Permanent Teeth \\
F & Adper Easy Bond (3M ESPE) & Total-etch Permanent Teeth \\
\hline
\end{tabular}

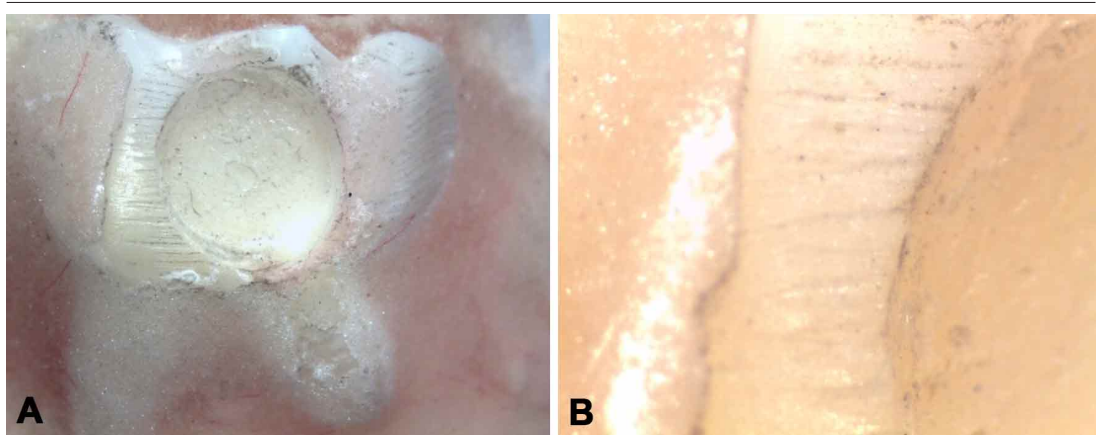

Fig. 1. A. Vestibular surface of temporal tooth after the compressive test, B. Complete composite release.

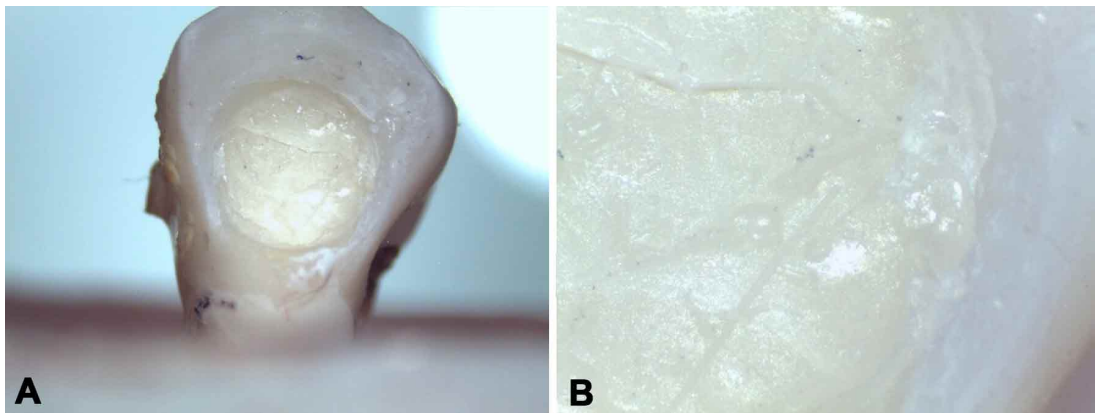

Fig. 2. A. Vestibular surface of permanent tooth after the compressive test, B. Partial composite release and patterns of cracks.
No significant differences also were found applying additional acid etching to specimens with Adper Easy Bond compared to self-etched technique. However, a decrease in bond strength values of PT and an increment in DT, observed when dentin was further etched (groups $C$ and D).

The adhesion in the dentin of deciduous teeth showed no significant statistic difference in groups $A$, B and C (Adper Single Bond 2, Adper Easy Bond and Adper Easy Bond modified with acid etching respectively).

In permanent teeth there was a significant statistic difference $(p=0.031)$ between groups $D$ and $F$, which means that better bonding strength is obtained by using the Single Bond 2 Adper systems (fifth complete etching-generation) respect to Adper Easy Bond (seventh generation or self-etching), although there wasn't significant statistic difference $(p=0.704)$ between the groups $\mathrm{E}$ and $\mathrm{F}$.

With Single Bond 2 PT $(p<0.05)$, Adper (Group D) was used. Nevertheless, Single Bond 2 Adper (group A) and Adper Easy bond with acid etching prior to its collocation (group C) on the primary teeth resulted similar to the $\mathrm{PT}$ (groups $\mathrm{E}$ and F). The Easy Bond Adper adhesive in DT (group B) presented the lower bonding strength values $(p<0.05)$, compared with use of any other system employed in this study regarding $\mathrm{PT}$ (groups D, E, F).

Composite release and crack. Respect to the release, two different types were found after compressive test, one in block mainly in temporal specimens and another like composite crack in permanent specimens. On Figures 1 and 2 is observed the difference between complete composite release in 1a), and partial composite release $2 a$ ) on permanent tooth. 


\section{DISCUSSION}

Previous studies reported different bond strength values in DT employing the fifth generation adhesives such as Prime \& Bond NT Dual Cure systems, with averages of $12.8 \pm 1.5 \mathrm{MPa}$ (Agostini et al.). Stanlin et al reported averages of $12.92 \pm 1.77 \mathrm{MPa}$ for Single bond, while Bolaños-Carmona et al. (2006), reported 13.43 $\pm 5.91 \mathrm{MPa}$ for Excite and finally Gateva \& Dikov (2012) mentioned averages of $11.72 \pm 1.54 \mathrm{MPa}$ for the seventh generation of adhesives such as Adhese One.

In the present study, the bond strength of a total etch Adper Single Bond 2 (fifth generation) in primary teeth showed a mean of $16.87 \pm 9.5 \mathrm{MPa}$ and 12.97 $\pm 8.03 \mathrm{MPa}$ for a self-etch Easy Bond Adper system (seventh generation). Moreover, an additional acid etching on dentin before Adper Easy Bond test showed a mean value of $17.43 \pm 9.91 \mathrm{MPa}$. Our results are in accordance with findings from studies addressing the same comparisons, stating that acid etching to dentin prior self-etch adhesives provide better bonding strength results.

Since bond strength adhesive systems are a major concern in $\mathrm{PT}$, a previous study showed bond strength values of $25.6 \pm 5.7 \mathrm{MPa}$ with Single Bond 2 (Barajas \& Barceló, 2007). Furthermore, Hegde \& Bhandary reported $26.09 \pm 0.55 \mathrm{MPa}$ with total etch Prime \& Bond NT Dual Cure bonding system, and $24.52 \pm 0.53 \mathrm{MPa}$ with self-etch Clearfil S3, also values of $16.37 \pm 0.64 \mathrm{MPa}$ with self-etch G Bond. Faria-E-Silva et al. (2009) described a bonding strength of $10.18 \pm 3.62 \mathrm{MPa}$ with iBond; in the same way, Gateva \& Dikov reported $6.88 \pm 1.28 \mathrm{MPa}$ with the Adhese One system. On the present study results revealed high values of $38.86 \pm 20.46 \mathrm{MPa}$ for Adper Single Bond 2, while averages of $26.54 \pm 9.21 \mathrm{MPa}$ for Adper Easy Bond modified acid etching to dentin. Our finding suggests that the additional etching to dentin applied with Adper Easy Bond makes no difference in bond strength.

\section{CONCLUSIONS}

1. Shear bond strength of adapter composites observed superior on permanent teeth respect to temporal

2. Adper Easy Bond (3M) and total-etch manifest averages values of $17 \mathrm{MPa}$ in deciduous teeth while
Adper Single Bond $2(3 \mathrm{M})$ and total-etch manifest values greater than $38 \mathrm{MPa}$ in permanent teeth

3. Not statistical differences observed between all deciduous teeth groups and between all permanent teeth groups.

4. Release observed different between permanent and deciduous teeth after the compressive test, while in deciduous was total release detachment, in permanent presented mainly in partial way with composite cracks.

\section{ACKNOWLEDGMENTS}

The authors would like to thank Eng. Arturo Hernandez for the evaluations and management of Intron machine, also to the Centro de Investigación en Materiales Avanzados S.C CIMAV for the assistance and facilities.

MARTÍNEZ-CARRASCO, C. A.; NEVÁREZ-RASCÓN, A. \& SOTO-BARRERAS, U. Evaluación comparativa de la fuerza de unión de los sistemas de adhesivo dental autograbado y grabado total para la dentina de dientes deciduos y permanentes. Int. J. Odontostomat., 14 (1):55-59, 2020.

RESUMEN: El objetivo de este estudio fue analizar la fuerza de unión de los sistemas adhesivos de grabado total y autograbado a la dentina de los dientes primarios y permanentes. Métodos: treinta sonidos exfoliaron naturalmente los molares primarios dientes caducifolios (DT) y treinta sonidos. Los dientes permanentes de los premolares permanentes (PT) se dividieron aleatoriamente en seis grupos ( $n=10$ por grupo) de acuerdo con dos sistemas adhesivos comerciales: Adper Single Bond 2; 3M ESPE (Grabado total) y Adper Easy Bond; $3 \mathrm{M}$ ESPE (autograbado y grabado total). Muestras sometidas a carga cíclica en una máquina universal de pruebas Instron. Los valores de resistencia de la unión (MPa) se analizaron mediante la prueba ANOVA y la prueba post hoc de Duncan (a $=0.05$ ). Resultados: Los valores medios fueron mayores en PT en comparación con DT. En dientes deciduos, no se observaron diferencias significativas. Total etch AdperTM Single Bond 2 mostró una fuerza de unión significativamente mayor que la autograbado AdperTM con grabado ácido adicional en PT ( $p=$ 0.031). Conclusión: Nuestros hallazgos sugieren que la mayor fuerza de unión se encontró en el tejido de dentina de PT con grabado total AdperTM empleando el adhesivo Single Bond 2 de autograbado de un solo paso.

PALABRAS CLAVE: sistemas adhesivos, fuerza de unión, dientes permanentes, dientes caducifolios. 


\section{REFERENCES}

Agostini, F. G.; Kaaden, C. \& Powers, J. M. Bond strength of selfetching primers to enamel and dentin of primary teeth. Pediatr. Dent., 23(6):481-6, 2001.

Barajas, V. L. \& Barceló, F. Estudio comparativo de adhesión a dentina por medio de resistencia al desalojo por empuje entre sistemas con y sin grabado ácido. Rev. Odontol. Mex., 11(4):181-4, 2007.

Bolaños-Carmona, V.; González-López, S.; Briones-Luján, T.; De Haro-Muñoz, C. \& de la Macorra, J. C. Effects of etching time of primary dentin on interface morphology and microtensile bond strength. Dent. Mater., 22(12):1121-9, 2006.

Castro, C. G.; Filho, P. C.; da Mota, A. S.; Campos, R. E. \& Soares, C. J. Effect of a bonding resin layer associated with a self-etching adhesive system on the bond strength of indirect restorations. J. Appl. Oral Sci., 15(2):94-8, 2007.

Cavalcanti, A. L.; Melo, T. R. N. B.; Maia, A. M. A.; Souza, R. O. A. \& Salazar-Silva, J. R, Resistencia al cizallamiento de dos sistemas adhesivos autocondicionantes en dientes decíduos - estudio in vitro. Acta Odontol. Venez., 46(2):176-9, 2008.

Chowdahary, N. \& Subba Reddy, V. V. Dentin comparison in primary and permanent molars under transmitted and polarised light microscopy: an in vitro study. J. Indian Soc. Pedod. Prev. Dent., 28(3):167-72, 2010.

Faria-E-Silva, A. L.; Fabião, M. M.; Sfalcin, R. A.; de Souza Meneses, M.; Santos-Filho, P. C.; Soares, P. V. \& Martins, L. R. Bond strength of one-step adhesives under different substrate moisture conditions. Eur. J. Dent., 3(4):290-6, 2009.

García-Godoy, F. \& Donly, K. J. Dentin/enamel adhesives in pediatric dentistry. Pediatr. Dent., 24(5):462-4, 2002.

Gateva, N. \& Dikov, V. Bond strength of self-etch adhesives with primary and permanent teeth dentin - In vitro study. JIMAB, 18(2):168-73, 2012

Hegde, M. \& Bhandary, S. An evaluation and comparison of shear bond strength of composite resin to dentin, using newer dentin bonding agents. J. Conserv. Dent., 11(2):71-5, 2008.

Jaques, P. \& Hebling, J. Influência da esterilização de dentes humanos em autoclave sobre a resistência de união resina/dentina. Pesqui. Bras. Odontopediatria Clin. Integr., 6(1):9-13, 2006.

Mai, S.; Kim, Y. K.; Kim, J.; Yiu, C. K.; Ling, J.; Pashley, D. H. \& Tay, F. R. In vitro remineralization of severely compromised bonded dentin. J. Dent. Res., 89(4):405-10, 2010.

Mazzeo, N.; Ott, N. W. \& Hondrum, S. O. Resin bonding to primary teeth using three adhesive systems. Pediatr. Dent., 17(2):112-5, 1995.

Mortazavi, V.; Fathi, M. \& Vafaie, P. Effect of the type of restorative material on bonding efficacy and microleakage of a self-etching adhesive system. J. Res. Med. Sci., 9(4):152-7, 2004.

Nör, J.; Feigal, R. J.; Denisson, J. B. \& Edwards, C. A. Dentin bonding: SEM comparison of the resin-dentin interface in primary and permanent teeth. J. Dent. Res., 75(6):1396-403, 1996.

Prabhakar, A. R.; Raj, S. \& Raju, O. S. Comparison of shear bond strength of composite, compomer and resin modified glass ionomer in primary and permanent teeth: an in vitro study. $J$. Indian Soc. Pedod. Prev. Dent., 21(3):86-94, 2003.

Schmitt, D. C. \& Lee, J. Microleakage of adhesive resin systems in the primary and permanent dentitions. Pediatr. Dent., 24(6):58793, 2002.

Stanlin, A.; Varma, B. R. \& Jayanthi. Comparative evaluation of tensile-bond strength, fracture mode and microleakage of fifth, and sixth generation adhesive systems in primary dentition. J. Indian Soc. Pedod. Prev. Dent., 23(2):83-8, 2005.
Corresponding author:

C. A. Martinez-Carrazco MÉXICO

Email: aimee_mtz@hotmail.com

Received: 18-09-2018

Accepted: 26-08-2019 